\title{
Kemiğin dev hücreli tümörü
}

\author{
Giant cell tumor of bone
}

\author{
Mehmet Ali Deveci, Ömer Sunkar Biçer, Mustafa Tekin \\ Çukurova Üniversitesi Tıp Fakültesi, Ortopedi ve Travmatoloji Anabilim Dalı, Adana
}

Kemiğin dev hücreli tümörü, sıklıkla üçüncü dekatta görülen ve fizisi kapalı uzun kemiklerin metafizer bölgesine yerleşen iyi huylu ancak agresif bir tümördür. Kortekste incelme ve ekspansiyon yapan eksentrik yerleşimli litik lezyona yumuşak doku komponenti de eşlik edebilir. Geleneksel olarak intralezyonel küretaj ve "burr" uygulama sonrası lokal adjuvanlar ve çimentolama ile tedavi edilmesine karşın, \%25'lere varan lokal nüks oranları görülür. Son yıllarda tümörün patolojik özelliklerinin yanı sıra dev hücrelerin farklılaşması için başta nükleer faktör kappa B (NF-кB) ligand reseptör aktivatörü (RANKL) olmak üzere moleküler ve genetik özelliklerin tanınması, dev hücreli tümörün tedavisinde yeni hedefler ortaya çıkarmıştır. RANKL için insan monoklonal antikoru olan Denosumab'ın kullanılması, dev hücreli tümörün cerrahi olmaksızın tedavisini ve cerrahi sonrası nüks ihtimalinin azaltılmasını sağlamıştır.

Anahtar sözcükler: dev hücreli tümörler; cerrahi işlem; denosumab
Giant cell tumor of is a benign but aggressive tumor of the bone, most frequently seen in the third decade and generally localized in the metaphases of the long bones after the physeal closure. The excentric lytic lesion causes cortical expansion as well as thinning, and the tumor may also have a soft tissue component. Nearly $25 \%$ local recurrence is seen in spite of the treatment modalities such as intralesional curettage, local adjuvant usage after high speed burring, and bone cement. In recent years, recognition of pathologic properties of the tumor as well as the molecular and genetic such as nuclear factor kappa B (NF-kB) ligand receptor activator (RANKL) has defined new targets in the treatment of the giant cell tumor. The use of denosumab, which is the human monoclonal antibody of RANKL, has provided treatment without surgery and decreased the recurrence rate after surgery.

Key words: giant cell tumors; operative surgical proceedure; denosumab
K emiğin dev hücreli tümörü (DHT) 1818'de Cooper ve Travers tarafindan tanımlanmış$\operatorname{tır}^{[1]}$. Ancak ilk klinik, patolojik ve radyolojik özellikler 1940'da Jaffe tarafından bildirilmiştir. ${ }^{[2]}$ Çok çekirdekli dev hücreler içeren lezyon, kemiğin sıklıkla metafizine yerleşen iyi huylu ancak agresif bir tümördür. Bu çok çekirdekli dev hücreler osteoklastlara benzediğinden kemiğin dev hücreli tümörü osteoklastom olarak da adlandırılmaktadır. ${ }^{[3]}$

Dev hücreli tümör uzun kemiklerin metafizine yerleşir. Sıklıkla fizisler kapandıktan sonra ortaya çıkar. Eksentrik yerleşimli tümörün sınırları net olarak görülebilir ancak çevreleyen sklerotik bir kenar bulunmaz. Dev hücreli tümör coğrafik paterni, kortikal destrüksiyon yapması, yumuşak doku komponenti olması ve içerisinde SIVI - sIVI seviyeleri bulundurması gibi agresif özellikler içermesi nedeniyle hem radyolojik hem de patolojik olarak tanı zorluğu yaratabilen bir tümördür. Çeşitli tedavi yöntemlerinin kullanılmasına rağmen nüks ihtimali her zaman fazladır. ${ }^{[4]}$

Son yıllarda, DHT'nin moleküler ve hücresel biyolojisinin anlaşılması ile başta bifosfonatlar ve denosumab olmak üzere cerrahi dışı tedavi seçeneklerinin gelişmesi, bu tümörlerin tekrarlama oranlarının azalmasını sağlamıştır.

\section{EPIDEMIYOLOJi}

DHT, tüm kemik tümörlerinin \%5'ini, iyi huylu kemik tümörlerinin ise yaklaşık \%20'sini oluşturur. Sarı ırkta (özellikle Hindistan ve Çin'de) sık görülür. ${ }^{[5]}$ Kadınlarda daha sık karşımıza çıkar. Oluşumu için saptanan bir risk faktörü bulunmamakla beraber DHT ve Paget hastalığı ile ailesel geçiş saptanmıştı. ${ }^{[6]}$

- Illetişim adresi: Yrd. Doç. Dr. Mehmet Ali Deveci, Çukurova Üniversitesi Tıp Fakültesi, Balcalı Hastanesi, Ortopedi ve Travmatoloji Anabilim Dalı, Balcalı, Sarıçam, Adana Tel: 0533 - 4797674 e-posta: drmehmetali@hotmail.com

- Geliș tarihi: 27 Eylül 2013 Kabul tarihi: 27 Eylül 2013 
Hastalar sıklıkla ağrı, eklem hareketlerinde kısıtlılık ve şişlik şikayeti ile başvurur. Hastaların yaklaşık \%30'unda, korteks destrüksiyonu sonucu patolojik kırık oluşumu karşımıza çıkar.

DHT en sık üçüncü dekatta görülür. Hastaların \%80'i 20-40 yaş arasındadır. Olguların yaklaşık \%3'ü 14 yaş altında görülürken, \%13 civarında lezyon 50 yaş üstünde ortaya çıkmaktadır. ${ }^{[7]}$ Lezyon en sık (\%75-90) fizisi kapanmış uzun kemik metafizlerinde yerleşir. Görülen olguların \%50-65’i diz çevresinde distal femur veya proksimal tibia yerleşimlidir. Distal radius da üçüncü sık tutulan lokalizasyondur. Olguların yaklaşık \% 15 'i pelvis, sakrum, omurga, kaburgalar ve kalvarial kemikler gibi yassı kemiklerde oluşur. DHT, Paget hastalığı zemininde de görülebilir ve sıklıkla kafa kemikleri, yüz kemikleri ve pelviste karşımıza çıkar. El ve ayak kemikleri nadir tutulan lokalizasyonlardır ve olguların \%2'sini oluşturur. Multisentrik DHT çok nadirdir (<\%1) ve en sık ekstremitenin distalinde el ve ayaklarda görülür. ${ }^{[2,4,7,8]}$

DHT metafizer yerleşimli bir lezyon olmasına karşın trokantör majör gibi epifiz eşdeğeri olan apofizer bölgelerde de nadiren karşımıza çıkmaktadır. Bu durumlarda etrafında skleroz olmayan litik lezyon görünümüne rastlanmayabilir. ${ }^{[9]}$

\section{GÖRÜNTÜLEME}

Dev hücreli tümörün düz radyografilerdeki görünümü tipiktir. Sınırları net olarak belirli, geniş geçiş zonuna sahip, coğrafik litik lezyon olarak karşımıza çıkar; ancak lezyon hızlı ve agresif bir seyir izlediği için çevresinde sklerotik bir kenar görünmez. Eksentrik yerleşimlidir. İçinde ince septasyonlar görülebilir. Metafizde yerleşen lezyon sıklıkla subkondral kemiğe kadar uzanır. Kortekste incelme ve genişleme ile kortikal destrüksiyon görülebilir. Patolojik kırık olmadığı durumlarda DHT eklemi nadiren invaze eder. Campanacci ve arkadaşlarının radyolojik incelemelerine göre DHT üç evreye ayrılmıştır. Evre 1'de agresif özellikler olmaksızın iyi sınırlı, kortekslerin sağlam olduğu litik lezyon mevcuttur (Şekil 1 a). Evre 2 tümörlerde kortikal incelme ve ekspansiyon bulunurken (Şekil 1 b) Evre 3 lezyonlarda kortikal destrüksiyon ve yumuşak doku komponenti bulunmaktadır (Şekil $1 \mathrm{c}$ ). Akciğer metastazlarının varlığı bu evrelemeyi etkilemez. ${ }^{[10]}$

Bilgisayarlı tomografi (BT) lezyonun kemik içinde yerleşimi, kortikal incelme ve destrüksiyon durumunun daha net incelenmesi için yardımcıdır. Patolojik kırığın değerlendirilmesinde de önemlidir. İki boyutlu sagittal ve koronal rekonstrüksiyonlar ile lezyonun yerleşimi daha iyi ortaya konabilir. Manyetik rezonans (MR) görüntüleme bulguları spesifik değildir. Genellikle T1 ağılıklı görüntülerde orta veya azalmış sinyal yoğunluğu varken, sıvı duyarlı sekanslarda artmış sinyal yoğunluğu vardır. İntravenöz kontrast madde enjeksiyonu sonrası heterojen tutulum mevcuttur. MR ile yumuşak doku komponentinin durumu, kıkırdak yakınlığı veya eklemin tutulumu daha ayrıntılı şekilde değerlendirilmelidir. DHT'ye \%14-25 oranında eşlik eden anevrizmal kemik kisti mevcut ise MR'de SIVI - SIVI seviyeleri karşımıza çıkabilir (Şekil 2).

Teknetyum-99m kemik sintigrafisi ile yapılan değerlendirmede, litik karakterinden dolayı lezyonun merkezinde fotopeni izlenirken, periferinde artmış radyonükleid tutulumu karşımıza çıkar. ${ }^{[4]}$

Mümkün olan durumlarda, 18-fluorodeoksiglukozPET ( ${ }^{18}$ FDG-PET) tümör metabolizması ve anjiyogenezi hakkında bilgi verir. DHT'nin metabolik aktivitesi osteoklast benzeri hücre popülasyonunun transmembran adenozin trifosfat (ATP) bağımlı proton pompa taşıyıcı proteinini yüksek miktarda içermesi nedeniyle yüksek olabilir. Bu yüksek metabolik aktivitenin habis transformasyon lehine düşünülmemesi gerekir. ${ }^{[11]}$

DHT'nin radyolojik değerlendirmesinde, agresif özellikler arasında geniş geçiş zonu bulunması, kortikal incelme, kortikal ekspansiyon ve destrüksiyon, eşlik eden yumuşak doku komponenti sayılabilir. Bu bulgular fibula, ulna gibi küçük çaplı kemiklerde daha sıktır ve çoğu zaman tanıyı zorlaştırır. ${ }^{[4]}$

Olguların \%1-6'sında akciğer metastazları görülebilir. Bu metastazlar sıklıkla hematojen yolla oluşur ve DHT tedavisi sonrasında gelişmeye meyillidir. Pulmoner lezyonlar sıklıkla primer kemik tümörlerinin metastazları ile aynı radyolojik görünüme sahiptir ancak histolojik olarak selim karakterdedir. Soliter akciğer lezyonları eksize edilebilir ancak multipl lezyonlar genellikle sorun çıkarmaz ve tedavi gerektirmez. ${ }^{[12]}$

\section{AYIRICI TANI}

Anevrizmal kemik kisti, DHT olgularının yaklaşık \%14-30'una eşlik edebilir. Bu iki lezyon hem radyolojik hem de patolojik analiz sırasında birbiriyle karışabilir ve tanıda sorunlara neden olabilir. Görüntüleme yöntemleri ile yumuşak doku komponenti bulunması anevrizmal kemik kisti olgularında sık görülmez. DHT'de kist boşluklarının içinde kanama meydana gelmesi, özellikle MR'de sIVı - sıVı seviyelerinin görülmesine neden olabilir.

Subkondral kemiğe uzanan ekspansil kemik metastazları (en sık renal hücreli karsinom ve tiroid karsinomları) ile plazmasitom veya multipl miyelom gibi hematolojik tümörler de DHT ile karışabilir. Kırk yaşın üzerindeki hastalarda görülen multipl lezyonlarda metastaz ve multipl miyelom ayırıcı tanıda daha ön planda düşünülmelidir. 

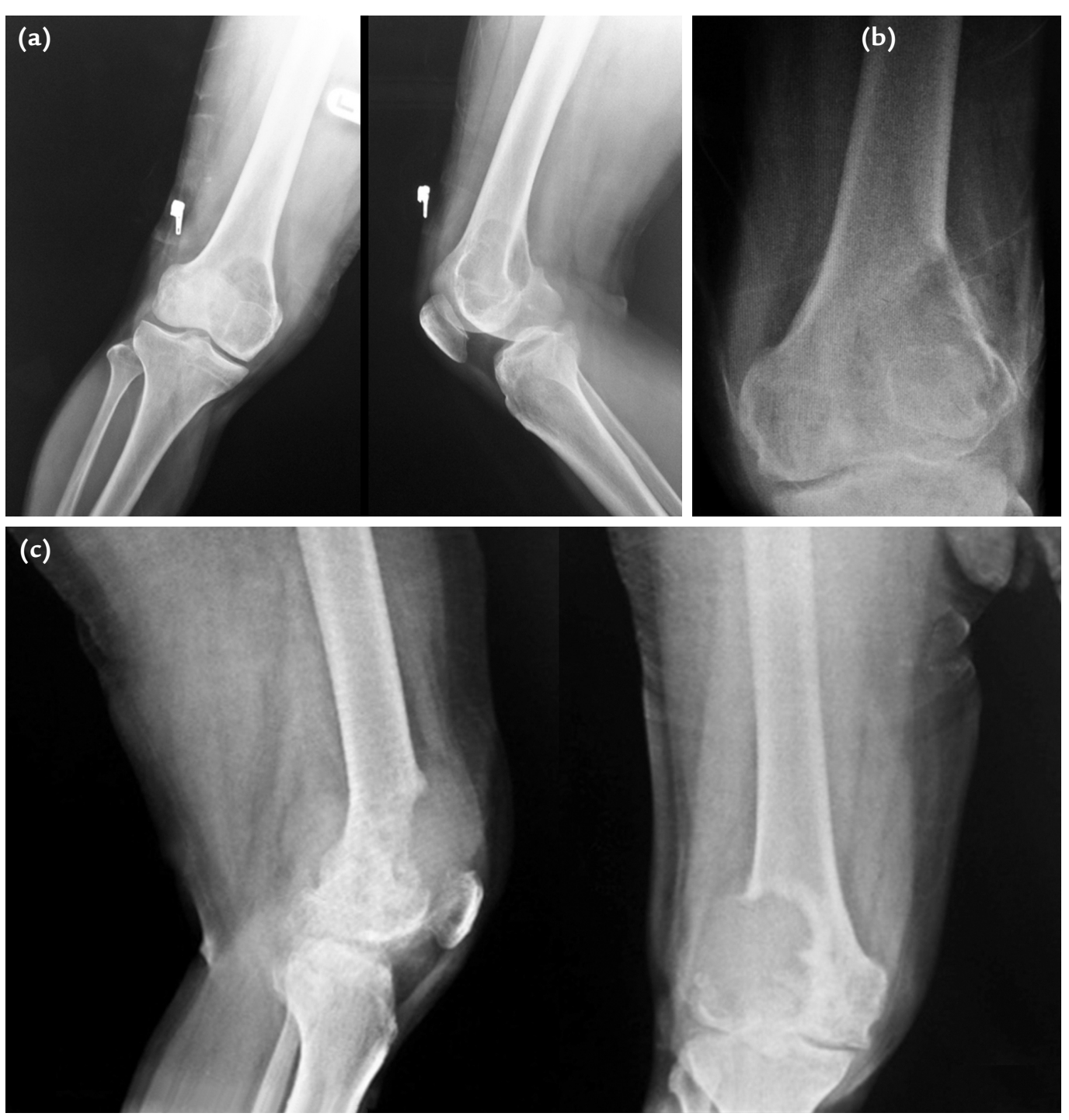

Şekil 1. a-c. Sol

femur medial kondile yerleşimli dev hücreli tümör. Evre 1 lezyonda agresif özellikler olmaksızın iyi sınırlı, kortekslerin sağlam olduğu litik lezyon mevcuttur (a). Evre 2 tümörlerde kortikal incelme ve ekspansiyonu gösteren düz radyografiler (b). Evre 3 tümörde kortikal destrüksiyon ve yumuşak doku komponenti karşımıza çıkar (c).

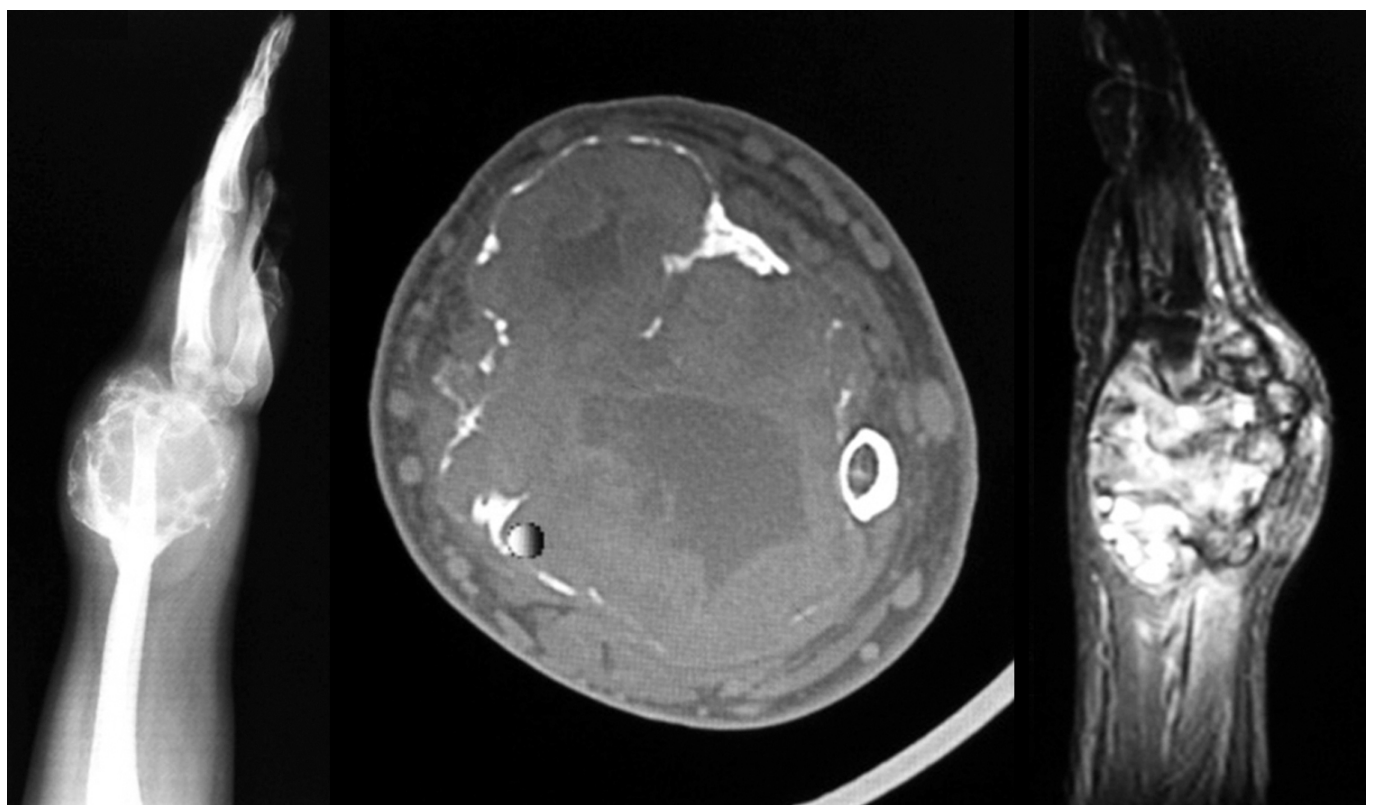

Şekil 2. Sağ radius distalinde dev hücreli tümörü gösteren düz grafi, BT ve MRG kesitleri. Tümörün yaygın korteks destrüksiyonu, ekspansiyonu yaptığı ve geniş yumuşak doku komponenti olduğu görülmektedir. 
Epifiz yerleşimli bir lezyon olan kondroblastom da ayırıcı tanıda yer almalıdır. Yumuşak doku komponentinin ve MR'de kemik iliği ödemi varlığı, bu iki lezyonun ayrımı için yeterlidir. Kondroblastom bir sklerotik kenar tarafindan çevrelenir ve merkezinde kondroid matriks nedeniyle gelişen "halka ve ark paterni" (ring and arc pattern) vardır.

Telanjektatik osteosarkom, dev hücreden zengin osteosarkom ve fibroblastik osteosarkom gibi osteoid matriks üretmeyen osteosarkom alt tipleri de DHT'yi taklit edebilir. Berrak hücreli kondrosarkom da kemiğin epifizometafizer bölgesinde yerleşen nadir bir tümördür. Kondroid matriks, olguların sadece 1/3'ünde görüldüğünde ayırıcı tanı için yeterlidir.

Dev hücreli tümör ekleme yaklaştığında pigmente villonodüler sinovit veya sinoviyal kondromatozis gibi eklemi oluşturan kemiklere bası erozyonu yapan lezyonlarla karışabilir. Ancak bu lezyonlar eklemin her iki tarafını da ilgilendirir. DHT genellikle eksentrik yerleşimlidir ve eklemi geçmez.

Omurganın ve sakrumun DHT'si nadir olarak görülmekle birlikte, özellikle sakrumda yerleşen ve yumuşak doku komponentinin eşlik ettiği olgularda ayırıcı tanıda kordom düşünülmelidir. Kordomların orta hat yerleşimli olmaları, sekestre kemik fragmanları veya kalsifikasyon alanları içermeleri ayırıcı tanıda önemlidir.

Hiperparatiroidizmde ortaya çıkan Brown tümörü hem radyolojik hem de patolojik incelemede DHT ile karışabilir. Nadir görülen multisentrik olgularda parathormon seviyelerinin ölçümü ayırııı tanı için sıklıkla yeterlidir.

\section{HABIS TRANSFORMASYON}

DHT nadiren habis transformasyona uğrayabilir. Bu oran sıklıkla \%1'in altındadır. ${ }^{[13]}$ Bu dönüşüm primer tümörün dediferansiyasyonu veya daha önceki radyoterapi uygulamasına sekonder olabilir. ${ }^{[13]}$ Sıklıkla kötü prognoza sahip yüksek dereceli sarkomlara rastlanır. Bertoni ve arkadaşları DHT tanısı sonrası sarkoma dedifferasiyasyon gelişimi süresinin radyasyon tedavisi alan hastalarda ortalama $9 \mathrm{yll}$, almayanlarda ise $19 \mathrm{yll}$ olduğunu bildirmişlerdir. ${ }^{[14]}$

\section{PATOLOJI VE PATOJENEZ}

Makroskopik olarak DHT, kemiği erode eden hemorajik, yumuşak, lobüle, koyu kahverengi yumuşak doku ile karakterizedir. Küçük nekrotik alanlar, kistler ve kan ile dolu boşluklar bulunabilir. Mikroskopik olarak incelendiğinde, tümör mononükleer spindlebenzeri stromal hücre popülasyonu, mononükleer monositler ve atipi olmadan merkezi yerleşimli çekirdekler içeren tipik çok çekirdekli dev hücrelerden oluşur (Şekil 3). Bu belirgin çok çekirdekli dev hücreler, monosit öncüllerinden meydana gelmiştir ve tümörün \%50'sinden fazlasını oluşturabilir. Dev hücreler tümör tarafından gerçekleştirilen aşırı kemik rezorpsiyonundan sorumlu iken, spindle benzeri stromal hücreler tümör patolojisini yöneterek monositleri yönlendirir ve birleşerek dev hücreler oluşturmalarına neden olur. ${ }^{[15]}$ Bu dev hücreler; CD68, CD163 ve matür osteoklast belirteçlerinden olan tartrate-dirençli asit fosfataz içerir. ${ }^{[10]}$ Mikroarray temelli çalışmalar bu hücrelerin birçok osteoklast işaret genlerini -katepsin K, kreatin
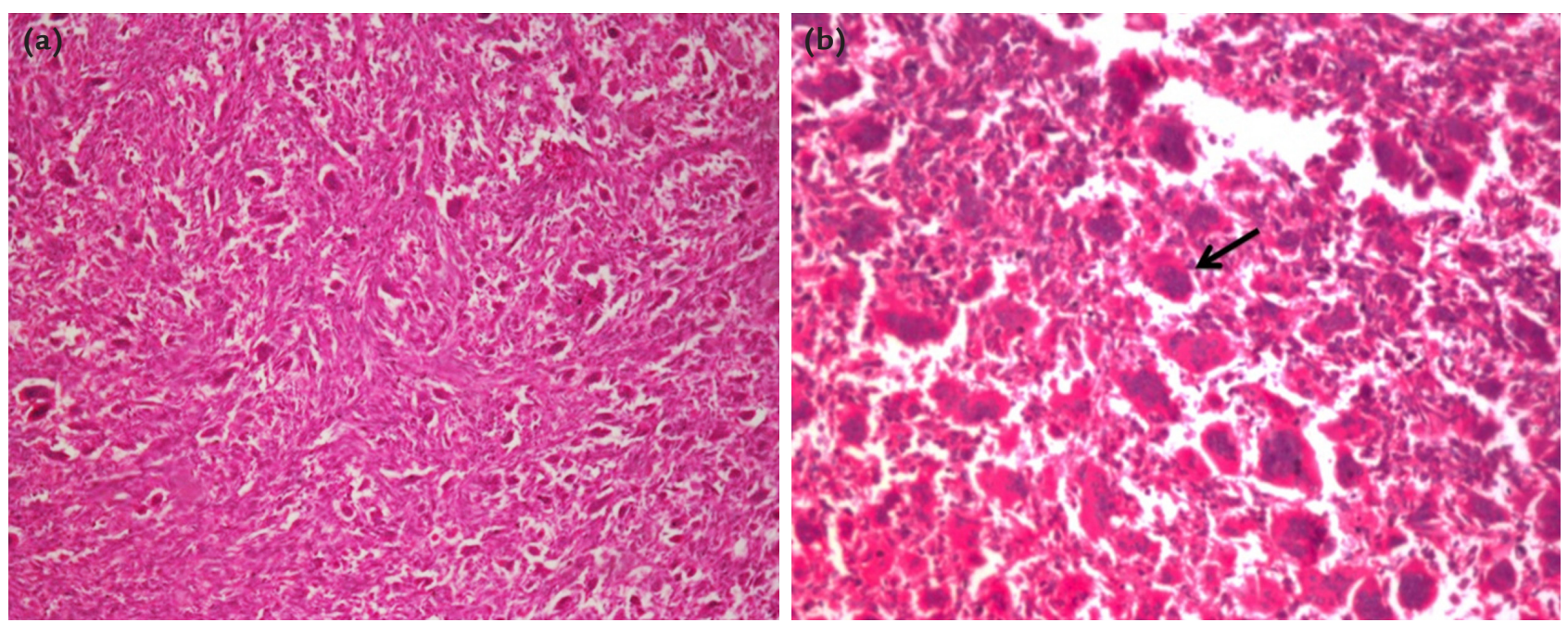

Şekil 3. a, b. Dev hücreli tümörün tipik patolojik görünümü. Spindle hücrelerin ve mononükleer hücrelerin içine yayılmış yaygın dev hücreler (a). Dev hücrelerin (ok) büyük büyütmedeki görünümü (b). (Çukurova Üniversitesi Tıp Fakültesi Patoloji Anabilim Dalı arşivi, Prof. Dr. Gülfiliz Gönlüşen'in izni ile) 
kinazın beyin izoformu, timidin kinaz, aktif T hücrelerin kalsinorin-bağımlı nükleer faktörü ve membran assosiye ATP bağımlı proton pompa genlerini- artmış şekilde aktive ettiğini göstermektedir. ${ }^{[16]}$ Eşlik eden stromal hücreler immatür osteoblastlara benzer ve alkalin fosfotaz, osteokalsin, lumican, decorin, Tip 1 kollajen ve kollajenaz 3 içerir. ${ }^{[17]}$ Tümör içindeki kanama alanlarında anevrizmal değişiklikler gözlenebilir. ${ }^{[15]}$

Klinik olarak en önemli noktalardan biri DHT'nin nadir çeşidi olan habis dev hücreli tümörün ayırt edilmesidir. Dev hücreler içinde nükleer atipi ve immatür osteoid oluşumu habis transformasyon için dikkat çekmelidir.

DHT'nin patogenezindeki en önemli gelişme bir osteoklast farklılaşma faktörü olan "nükleer faktör kappa B reseptör aktivatörü"nün (RANKL) bulunmasıdır. Osteoklastlar dolaşımdaki hematopoetik hücrelerden, muhtemelen monosit öncüllerinden gelişir. 1990 'ların sonunda in vitro ve in vivo ortamda osteoklastların oluşabilmesi için RANKL'nin mutlaka olması gerektiği bulunmuştur. ${ }^{[16]}$ RANKL sinyalinin üç ana komponenti vardır. Reseptör, RANK, monositlerde yüksek oranda bulunur. Ligand, RANKL, stromal hücreler ve lenfositler başta olmak üzere birçok hücre türünde bulunabilir ve Tümör nekroze edici faktör (TNF) ailesinin bir üyesidir. Decoy reseptör olan Osteoprotegerin (OPG) RANKL'nin doğal negatif regülatörü olarak salınır. RANKL'si eksik farelerde osteopetrotik değişiklikler ortaya çıkar, dişler çıkamaz ve lenfosit oluşumunda eksiklikler görülür. ${ }^{[18]}$

Birçok çalışmada DHT'de yer alan stromal hücrelerde yüksek oranda RANKL bulunduğu gösterilmiştir. Bu nedenle bu stromal hücrelerin neoplastik sürecin başlangıcı olduğu ve RANKL'nin gerçek DHT patogenezinde kritik rol oynadığı düşünülmektedir. Dev hücreli tümörden elde edilen neoplastik stromal hücrelerin in vitro ortamda gözlenmesi sırasında RANKL ekspresyonunun hızlıca yok olduğunun saptanması, dev hücrelerden iletilen resiprokal sinyallerin stromal hücrelerin immatür durumda kaldığını ve RANKL ekspresyonu ile lizisi arttırdığını düşündürmektedir. Son dönemlerde bu RANKL'nin inhibisyonu ile osteoblastik aktivitenin arttırılabileceği ve dev hücreli tümörün tedavi edilebileceğine dair medikal tedavi girişimleri artmıştır. ${ }^{[18,19]}$

p63, dev hücreler içeren birçok tümörde pozitif olarak karşımıza çıkabilir. Yanagisawa ve arkadaşlarının yaptığı bir çalışmada DHT olgularının sadece $\% 36,3$ 'ünde $\mathrm{p} 63$ 'ün pozitif olmasına rağmen cerrahi sonrası nüks olan DHT olgularının $\% 73,6$ 'sında pozitif olması nedeniyle nüks için iyi bir prognostik faktör olabileceği belirtilmiştir. ${ }^{[20]}$

\section{TEDAVi}

DHT'nin tedavi seçenekleri son 30 yıldır pek değişmeden devam etmektedir. Geleneksel olarak Evre 1 ve Evre 2 lezyonların tedavisi; intralezyonel olarak küretaj, yüksek hızlı "burr", çeşitli adjuvanların kullanılması sonrası defektin kemik grefti veya kemik çimentosu ile doldurulmasıdır. Lokal nüks oranları \%15-25 arasında değişmektedir. ${ }^{[21]}$ Primer tedavi sırasında uygulanacak adjuvanlar arasında sıvı nitrojen, sıvı çinko klorid, fenol, argon lazer ve metilmetakrilat kullanımı sayılabilir. Sıvı nitrojen ile kriyoablasyon sonrası nüks oranları $\% 2,3$ 'lere kadar düşürülmüştür. Metilmetakrilat kullanımı ile hem oluşan defektin doldurulması hem de ISı ve sitotoksik etkisi nedeniyle cerrahi sınırların steril hale getirilmesi mümkündür. Metilmetakrilat kullanımının diğer bir avantajı ise oluşabilecek nükslerin radyolojik olarak erken dönemde saptanmasına olanak tanımasıdır. Subkondral yerleşimli lezyonlarda eklem kıkırdağının ısı etkisinden korunması amacıyla kıkırdağın altına kemik grefti uygulanması önerilmektedir (Şekil 4).

"En blok" rezeksiyon ve endoprotez ile rekonstrüksiyon, Evre 3 lezyonlarda, geniş yumuşak doku varlığında veya patolojik kırık varlığında uygulanabilir. Selim bir lezyon için tedavinin yaratacağı morbidite dikkate alınmalıdır. Literatürde intralezyonel cerrahi yaklaşımlar ve "en blok" rezeksiyonların benzer nüks oranları (yaklaşık \%6) bildirilmektedir. Pulmoner metastazlar için cerrahi tedavi genellikle gerekmez ancak yakın takip önemlidir.

Patolojik kırığın yumuşak doku yayılımı ile nüks olasılığını arttırdığına inanılsa da, son çalışmalarda uygun tedavi ile nüks oranlarının patolojik kırığı olmayan olgular ile aynı olduğu ortaya konmuştur. ${ }^{[21]}$ Van der Heijden ve arkadaşlarının 2013'te yaptıkları çalışmada, patolojik kırık ile başvuran DHT olgularında rezeksiyon ve adjuvanlar ile küretaj tedavisi karşılaştırılmıştır. Küretaj sonrası nüks oranı $\% 30$ iken rezeksiyon sonrası nüks oranının $\% 0$ olduğu bulunmuştur. Buna karşın küretaj uygulanan hastalarda MSTS (Musculoskeletal Tumor Society) skorlarının daha iyi olduğu ve daha az komplikasyon geliştiğini belirtmişlerdir. Sonuç olarak rezeksiyonun yumuşak doku yayılımı olan, kırıkla başvuran nüks olgularında ve küretaj sonrası yapısal bütünlüğün sağlanamayacağı olgularda uygulanmasını önermişlerdir. ${ }^{[22]}$

Kabul edilemeyecek kadar büyük morbidite yaratacak cerrahi planlanıyorsa (pelvis, omurga ve kranial kemikler) veya uygun cerrahi sınırlar elde edilemeyecek ise radyoterapi planlanabilir. Shi ve arkadaşlarının yaptığı çalışmada, on yıllık lokal kontrol oranının \%81 olduğu bildirilmiştir. Radyoterapinin takipte sekonder sarkom gelişimini uyardığı düşünülse de son çalışmalarda 


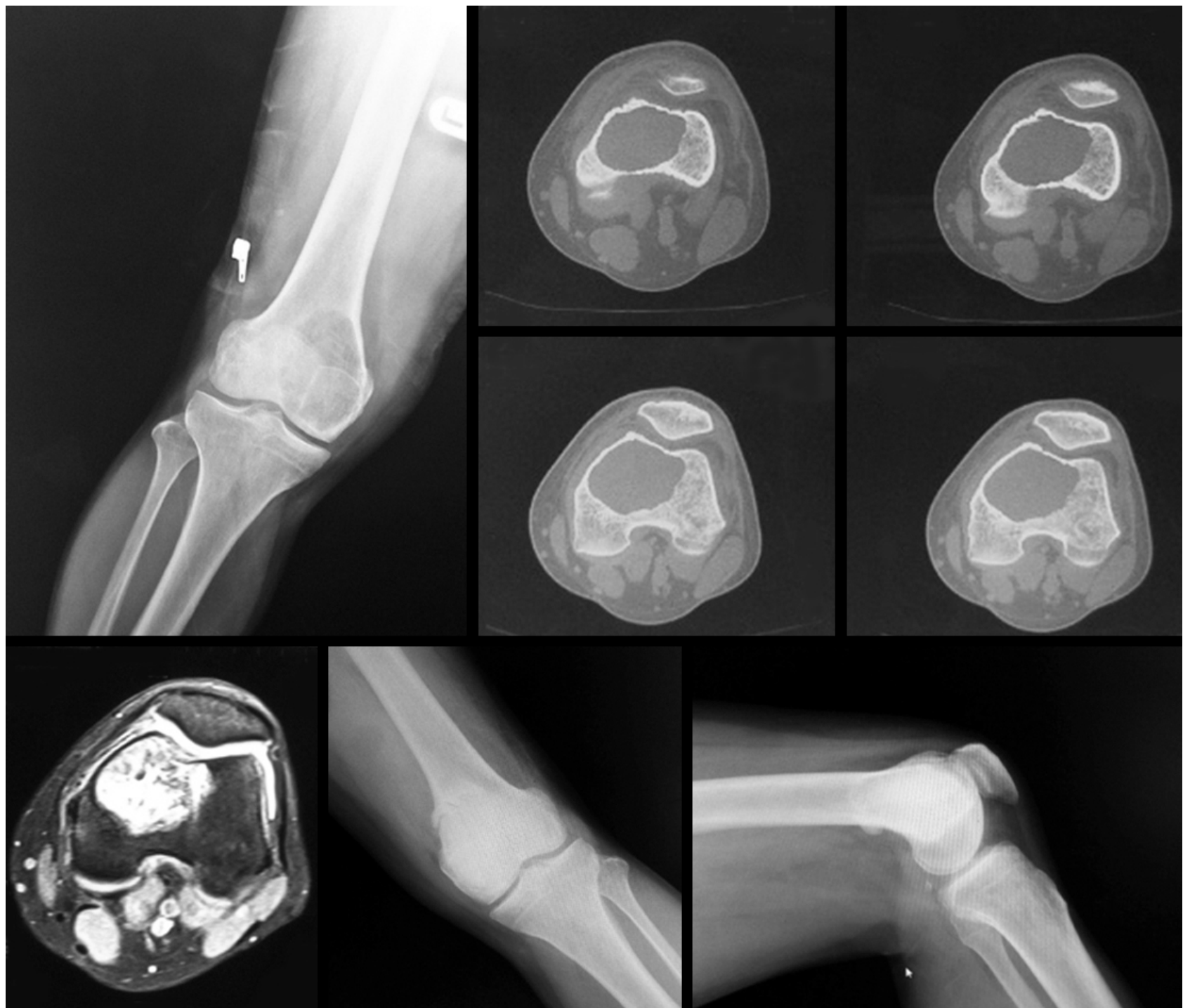

Şekil 4. Sol femurda dev hücreli tümör. Korteks destrüksiyonu bulunmayan, iyi sınırlı lezyona küretaj, yüksek hızlı burleme ve fenol uygulanması sonrasında kemik çimentosu uygulanması.

megavoltaj tekniğinin artmış sekonder habis transformasyona neden olmadığı gösterilmiştir. ${ }^{[23]}$

Rezeke edilmesi zor, ilerlemiş olgularda sitotoksik kemoterapi kullanımı ile ilgili birçok çalışma bulunsa da bunların hiçbiri randomize klinik çalışmalar değildir. Tümörün selim doğası ve tedavinin yan etkileri nedeniyle primer olarak tercih edilen bir tedavi yöntemi olmamıştır. Interferon- $\alpha$ kullanımı agresif olgularda denenmiş ancak yan etkileri nedeniyle vazgeçilmiştir.

Başta zolendronik asit olmak üzere bifosfonatların kullanımı ile DHT'de görülen stromal hücreler ve osteoklast benzeri dev hücrelerin yok edilmesi amaçlanmıştır. Ancak bifosfonat tedavisinin semptomatik iyileşme sağladığı ve nüksleri azalttığı gösterilmişse de tümördeki dev hücrelerde ve tümörün ossifikasyonunda etkili olmadığı bildirilmiştir. ${ }^{[10]}$

Son yıllarda, DHT'nin stromal hücreleri ve dev hücreleri arasındaki RANKL ilişkisinin daha iyi anlaşılması sonrasında Amgen tarafından geliştirilen RANKL'ye karşı insan monoklonal antikoru olan denosumabın DHT tedavisinde kullanımı gündeme gelmiştir. Thomas ve arkadaşlarının 2010'da yaptığı Faz 2 çalışmada, bir yıllık kullanım sonunda lezyondan dev hücrelerin tamamen temizlendiği ve radyolojik olarak lezyonun stabil kaldığı görülmüştür. Hastaların büyük kısmı ağrı ve fonksiyonel yetersizliğin azaldığını belirtmiştir. ilerleyen takiplerde litik lezyonun ossifiye olduğu izlenmiştir. Tedavinin ilk 4 haftasında elde edilen ${ }^{18}$ FDG-PET değerlendirmesinde tümörün metabolik 

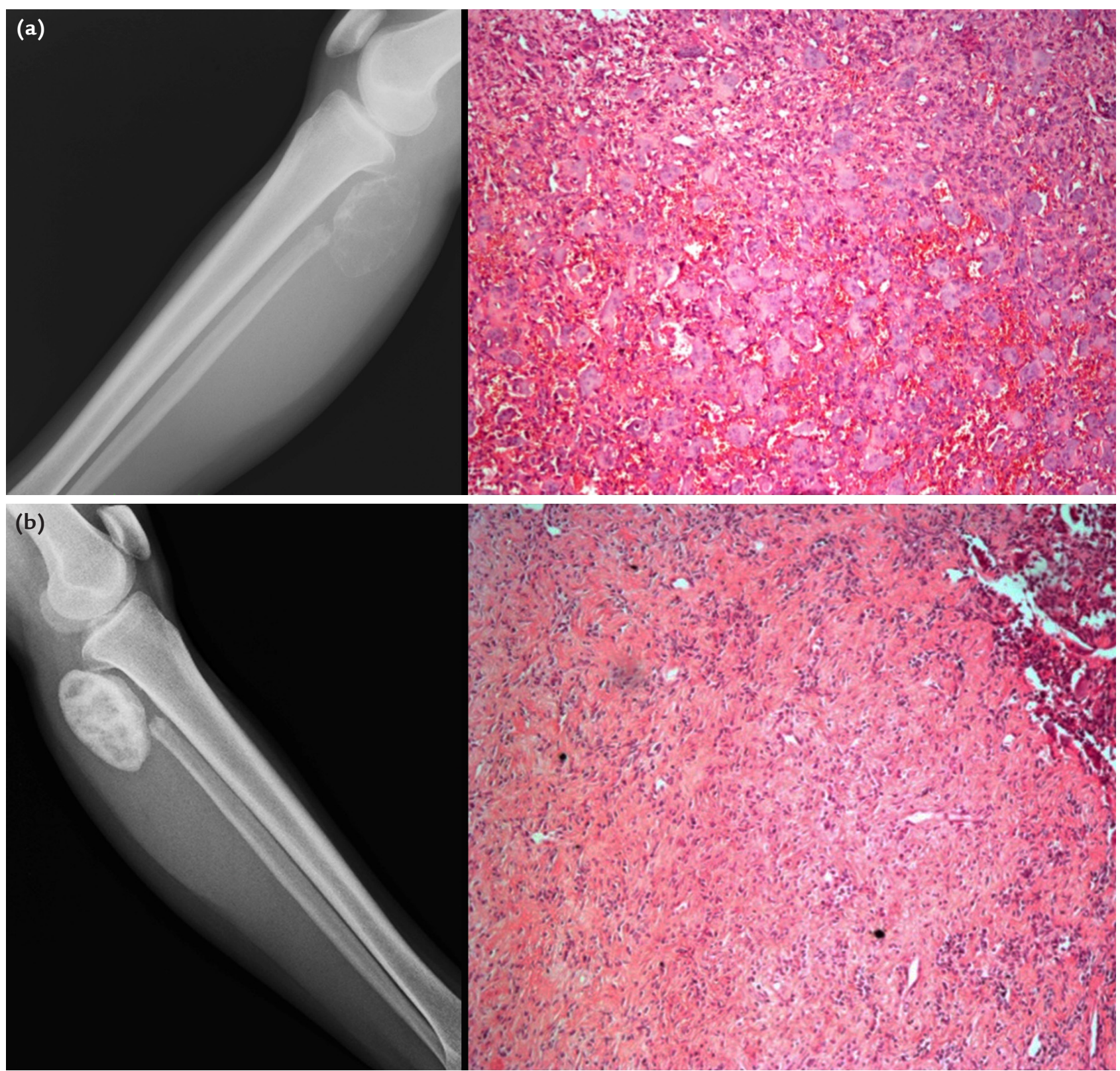

Şekil 5. a, b. Sol fibula proksimalinde dev hücreli tümör nedeniyle opere olan hastanın yumuşak dokuda nüks sonrası denosumab tedavisinin öncesinde ve sonrasındaki radyografi ve patoloji örnekleri. Denosumab tedavisi öncesi (a) ve sonrasında (b) patoloji örneklemesinde dev hücrelerin yok olduğu ve osteoblastik aktivitenin baskın olduğu görülmektedir.

aktivitesinde ciddi azalma saptamışlardır. İlk dozdan sonraki 28 gün içinde kemik döngüsü belirteçlerinden idrar N-telopeptid ve serum C-telopeptid düzeylerinde azalma saptanmıştır. ${ }^{[19]}$

Biz de kliniğimizde, özellikle daha önce ameliyat edilen nüks olgularda, denosumab $60 \mathrm{mg}$ subkutan (Prolia ${ }^{\circledR}$, Amgen-GlaxoSmithKline) kullanıyoruz. On kür sonunda takipteki altı olguda, başta ağıı olmak üzere klinik semptomlarda azalma, kortekslerde kalınlaşma ve kitle içinde ossifikasyon saptadık. Proksimal fibula yerleşimli lezyon nedeniyle ameliyat edilen ve yumuşak dokuda nüks nedeniyle tekrar başvuran bir olguda denosumab sonrası ciddi ossifikasyon gelişmişti ve rezeksiyon uygulaması sonrası yapılan patolojik değerlendirmede dev hücrelerin kaybolduğunu, osteoblastik aktivitede ve kemik yapımında artış olduğunu saptadık (Şekil 5). Patolojik kırık nedeniyle "en blok" rezeksiyon ve modüler protez ile rekonstrüksiyon yapılan akciğer metastazlı olguda ise cerrahi sonrası denosumab kullanımı ile metastazların stabil seyrettiğini ve bir yılık 
takipte lokal nüks olmadığını gözledik. Denosumab kullanımı ile, hafif grip benzeri semptomlar dışında yan etkiye rastlamadık.

\section{ÇIKARIMLAR}

Kemiğin selim ancak agresif tümörü olan DHT'nin tedavisinde en büyük sorun yüksek lokal nüks oranlarıdır. Son yıllarda DHT'nin hücresel ve moleküler biyolojisindeki gelişmeler ve RANKL ilişkisinin daha iyi anlaşılması ile, denosumab gibi hedefe yönelik tedavilerin tek başına veya cerrahi tedavi ile kombine olarak kullanılması ile yaşam kalitesinde artış ve lokal nüks oranlarında ciddi azalma sağlanabilecektir.

\section{KAYNAKLAR}

1. Balke M, Schremper L, Gebert $C$, Ahrens $H$, Streitbuerger A, Koehler G, Hardes J, Gosheger G. Giant cell tumor of bone: treatment and outcome of 214 cases. J Cancer Res Clin Oncol 2008;134(9):949-78. CrossRef

2. Jung ST, Park HW, Lee KB, Lee DH, Choi JI. Multicentric giant cell tumor in adolescents: three case reports. J Ped Orthop B 2013;22(3):282-7. CrossRef

3. Campanacci M, Baldini N, Boriani S, Sudanese A. Giant cell tumor of the bone. J Bone Joint Surg Am 1987;69(1):106-14.

4. Chakarun CJ, Forrester DM, Gottsegen CJ, Patel DB, White EA, Matcuk GR Jr. Giant cell tumor of bone: review, mimics and new developments in treatment. Radiographics 2013;33(1):197-211. CrossRef

5. Sung HW, Kuo DP, Shu WP, Chai YB, Liu CC, Li SM. Giantcell tumor of bone: analysis of two hundred and eight cases in Chinese patients. J Bone Joint Surg Am 1982;64(5):755-61.

6. Reddina D, Mossetti G, Soscia E, Sirignano C, Insabato L, Viceconti R, Ignarra R, Salvatore M, Nunziata V. Giant cell tumor and Paget's disease of bone in one family: geographic clustering. Clin Orthop Relat Res 2004;(421):218-24.

7. Werner M. Giant cell tumour of bone: morphological, biological and histogenetical aspects. Int Orthop 2006;30(6):484-9.

8. Hoch B, Inwards C, Sundaram M, Rosenberg AE. Multicentric giant cell tumor of bone. Clinicopathologic analysis of thirty cases. J Bone Joint Surg Am 2006;88(9):1998-2008.

9. Lichtinger TK, Heimkes B. Reconstruction of the greater trochanter with an allograft after resection of a giant cell tumor. Arch Orthop Trauma Surg 2004;124(10):715-7.
10. Thomas DM, Skubitz KM. Giant cell tumour of bone. Curr Opin Oncol 2009;21(4):338-44. CrossRef

11. Strauss LG, Dimitrakopoulou-Strauss A, Koczan D, Bernd L, Haberkorn U, Ewerbeck V, Thiesen HJ. 18F-FDG kinetics and gene expression in giant cell tumors. J Nucl Med 2004;45(9):1528-35.

12. Dominkus M, Ruggieri P, Bertoni F, Briccoli A, Picci P, Rocca $M$, Mercuri M. Histologically verified lung metastases in benign giant cell tumors - 14 cases from a single institution. Int Orthop 2006;30(6):499-504.

13. Kadowaki M, Yamamoto $S$, Uchio $Y$. Late malignant transformation of giant cell tumor of bone 41 years after primary surgery. Orthopedics 2012;35(10):1566-70. CrossRef

14. Bertoni F, Bacchini P, Staals EL. Malignancy in giant cell tumor of bone. Cancer 2003;97(10):2520-9.

15. Cowan RW, Singh G. Giant cell tumor of bone: a basic science perspective. Bone 2013;52(1):238-46. CrossRef

16. Morgan T, Atkins GJ, Trivett MK, Johnson SA, Kansara M, Schlicht SL, Slavin JL, Simmons P, Dickinson I, Powell G, Choong PF, Holloway AJ, Thomas DM. Molecular profiling of giant cell tumor of bone and the osteoclastic localization of ligand for receptor activator of nuclear factor kappaB. Am J Pathol 2005;167(1):117-28.

17. Ghert M, Simunovic N, Cowan RW, Colterjohn N, Singh G. Properties of the stromal cell in giant cell tumor of bone. Clin Orthop Relat Res 2007;459:8-13.

18. Thomas DM. RANKL, denosumab, and giant cell tumor of bone. Curr Opin Oncol 2012;24(4):397-403. CrossRef

19. Thomas D, Henshaw R, Skubitz K, Chawla S, Staddon A, Blay JY, Roudier M, Smith J, Ye Z, Sohn W, Dansey R, Jun S. Denosumab in patients with giant cell tumour of bone: an open-label, phase 2 study. Lancet Oncol 2010;11(3):275-80. CrossRef

20. Yanagisawa M, Kakizaki H, Okada K, Torigoe T, Kusumi T. p63 as a prognostic marker for giant cell tumor of bone. Upsala J Med Sci 2013;118(1):23-8. CrossRef

21. Klenke FM, Wenger DE, Inwards CY, Rose PS, Sim FH. Giant cell tumor of bone: risk factors for recurrence. Clin Orthop Relat Res 2011;469(2):591-9. CrossRef

22. Van der Heijden L, Dijkstra PD, Campanacci DA, Gibbons $C L$, van de Sande MA. Giant cell tumor with pathologic fracture: Should we curette or resect? Clin Orthop Relat Res 2013;471(3):820-9. CrossRef

23. Shi W, Indelicato DJ, Reith J, Smith KB, Morris CG, Scarborough MT, Gibbs CP Jr, Mendenhall WM, Zlotecki RA. Radiotherapy in the management of giant cell tumor of bone. Am J Clin Oncol 2013;36(5):505-8. CrossRef 